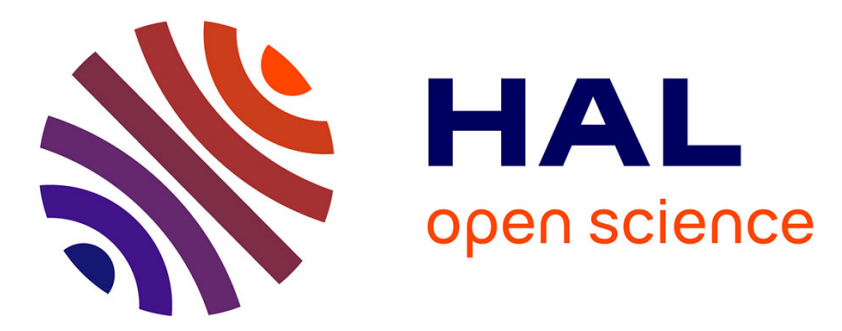

\title{
Modelling crop residue mulching effects on water use and production of maize under semi-arid and humid tropical conditions
}

Eric Scopel, Fernando A.M. da Silva, Marc Corbeels, François Affholder, Florent Maraux

\section{To cite this version:}

Eric Scopel, Fernando A.M. da Silva, Marc Corbeels, François Affholder, Florent Maraux. Modelling crop residue mulching effects on water use and production of maize under semi-arid and humid tropical conditions. Agronomie, 2004, 24 (6-7), pp.383-395. 10.1051/agro:2004029 . hal-00886027

\section{HAL Id: hal-00886027 https://hal.science/hal-00886027}

Submitted on 1 Jan 2004

HAL is a multi-disciplinary open access archive for the deposit and dissemination of scientific research documents, whether they are published or not. The documents may come from teaching and research institutions in France or abroad, or from public or private research centers.
L'archive ouverte pluridisciplinaire HAL, est destinée au dépôt et à la diffusion de documents scientifiques de niveau recherche, publiés ou non, émanant des établissements d'enseignement et de recherche français ou étrangers, des laboratoires publics ou privés. 


\title{
Modelling crop residue mulching effects on water use and production of maize under semi-arid and humid tropical conditions
}

\author{
Eric SCOPEL ${ }^{\mathrm{a}}$, Fernando A.M. DA SILVA ${ }^{\mathrm{b}}$, Marc CORBEELS ${ }^{\mathrm{a}}$, François AFFHOLDER ${ }^{\mathrm{a}}$, Florent MARAUX \\ ${ }^{\text {a }}$ Agrosystems Programme, Centre de coopération internationale en recherche agronomique pour le développement (CIRAD), avenue Agropolis, 34398 \\ Montpellier Cedex 5, France \\ ${ }^{\mathrm{b}}$ Centro de Pesquisa Agropecuária dos Cerrados (EMBRAPA-CPAC), CP 08223, 73301-970, Planaltina, DF, Brazil \\ ${ }^{\mathrm{c}}$ Agronomy Programme, Centre de coopération internationale en recherche agronomique pour le développement (CIRAD), avenue Agropolis, 34398 Montpellier \\ Cedex 5, France
}

(Received 12 June 2003; accepted 10 May 2004)

\begin{abstract}
A key principle of direct seeding mulch-based cropping systems is the retention of crop residues on the soil surface to preserve soil water for crop growth. In this study the impact of surface crop residue on water use and production risk associated with rainfall variability is analysed for two contrasting tropical sites. The two sites are La Tinaja in semi-arid Mexico and Planaltina in humid Brazil. The crop growth model STICS, version 3.0 was updated with a simple empirical module, incorporating the following effects of surface residue on soil water balance: (1) rainfall interception and subsequent mulch evaporation; (2) radiation interception with associated reduction of soil evaporation and (3) reduction of surface water runoff. The results of the model simulations showed that the effect of radiation interception at both sites was much more important than the effect of intercepting rain. The high sensitivity of model yield predictions to surface water runoff, especially in La Tinaja, highlighted the importance of a careful parameterisation of the surface water runoff formalism. The model results suggested that even small amounts of surface residue are effective at reducing water loss and increasing yield. In La Tinaja, grain yield was increased at least twofold with retention of $1 \mathrm{Mg} \mathrm{ha}^{-1}$ surface residue. In Planaltina, the advantage of water conservation by surface residue is partly offset by increased drainage losses. As a consequence, the impact of crop residue mulching on grain yield was lower at that site.
\end{abstract}

crop growth model / mulching / climatic risk / surface residue / water balance

\section{INTRODUCTION}

In response to the negative impact of soil degradation processes under 'conventional' cropping systems that are based on soil tillage [25], direct seeding mulch-based cropping (DMC) systems without tillage practices and with a protective cover of crop residues are being developed in many parts of the tropics. For example, in Brazil the area under DMC increased from 1 million ha in 1990 to 15 million in 2001 . Over the last 5 years, the greatest adoption of DMC systems in Brazil has been by large-scale farmers in the central tropical Cerrado region, where now over 4 million ha are cultivated using these practices [9]. Apart from the positive effect on soil conservation and sustained land productivity, another major impact of DMC is decreased labour costs, generally leading to higher income and a better standard of living for the farmers [24].

The DMC systems are based on four essential farming practices: (1) absence of soil tillage; (2) maintenance of a mulch of crop residues at all times; (3) direct seeding into crop residues, and (4) use of suitable crop successions [24]. The retention of crop residues on the soil surface is a key principle for reducing surface water runoff and erosion. A mulch of crop residues enhances water infiltration and protects the soil from sealing and crusting by rainfall $[10,18]$. Under semi-arid conditions surface plant residues also play an important role in conservation of soil water through reduced soil evaporation [27]. In addition, crop residues as a mulch moderate the temperature fluctuation in the top soil layer [7], which can enhance the activity of soil microorganisms and fauna [13], thus promoting the release of nutrients, improving water infiltration, and facilitating root development. Finally, a mulch of crop residues may also contribute to the control of weeds, by smothering them or through allelopathic effects [8].

Water is often a major limiting factor for crop production in the tropics, particularly in semi-arid regions. Soil water availability is directly related to environmental factors (including precipitation, evapotranspiration, soil type and topography), but may be influenced by agronomic practices, including irrigation, fallowing and sowing time, or via specific water conservation practices, such as terracing and mulching [17]. The water conservation effect of surface residue may potentially increase crop yields in tropical environments, where there is a risk of drought stress [14].

The effects of surface crop residue management need to be incorporated into simulation models that are used for predicting

* Corresponding author: Marc.corbeels@ cirad.fr 
and evaluating crop growth and yield in DMC systems. There exist a number of detailed, mechanistic models that have been developed to analyse mulch effects on coupled mass and heat transfers in the soil [7, 10, 20]. However, such models are not appropriate for agro-climatic analysis because of the large number of parameters, for which values are not always easy to obtain. STICS (Simulateur mulTIdisciplinaire pour les Cultures Standard) [5, 6] is a crop model which links crop growth to soil water and $\mathrm{C}$ and $\mathrm{N}$ dynamics. It relies essentially on wellknown generic relationships or on simplifications of existing models with an easy access to input data. STICS is capable of predicting effects of management practices such as fertiliser application, sowing date or irrigation on crop yield. Despite its wide application, STICS has not been fully tested for DMC systems with surface crop residue in tropical conditions.

The main objective of this study was to establish to what extent DMC effects on crop water balance may reduce production risk associated with rainfall variability for two tropical locations of contrasting climates. As a means of taking into account complex interactions between management practices and soil and weather conditions, we used STICS and analysed the effects of surface residue on production risk associated with rainfall variability for two sites. The STICS model, version 3 was improved by incorporating a module to simulate the effects of surface crop residue on water dynamics and tested at the two sites. A sensitivity analysis was performed to identify which components or processes of the surface residue module were most critical in predicting water use and maize yield at each site.

\section{MATERIALS AND METHODS}

\subsection{Model description}

For this study we adapted the crop growth model STICS, version 3.0 to account for the effects of surface crop residue on the water balance and final crop yield. STICS, version 3.0 is fully described in Brisson et al. [5].

STICS is an established and tested crop growth model $[5,6]$ that simulates processes of plant development and growth, as well as soil water and nitrogen balances on a daily time step. We chose to use STICS due to its successful application to various soil climate conditions [6]. Input variables and parameters relate to climate, soil and management practices (cultivar, sowing date, crop density, and fertiliser and irrigation application amounts and dates). Output variables relate to both agricultural productivity and sustainability (e.g. nitrate leaching).

The modified version of STICS that is described and used in this study considers that a mulch of surface residue affects soil water content through 3 processes: (1) rainfall interception and subsequent mulch evaporation; (2) radiation interception with associated reduction of soil evaporation, and (3) reduction of water runoff. Effects through changes in soil temperature or albedo by surface residue were not taken into account.

The following sections describe the modifications to STICS, version 3.0 introduced in this study and incorporated in STICS, version 5.0 [6]. The symbols used and their units are defined in Table A1 (see Appendix).

\subsubsection{Crop residue coverage}

Plant residues on the soil surface are treated as a separate component to residues incorporated in the soil and soil organic matter. The rate of surface residue decomposition is described by first-order kinetics:

$$
\mathrm{SR}=\mathrm{SR}_{\mathrm{O}} \exp (-k \mathrm{t})
$$

where SR is the mass of surface residue (expressed as dry matter, DM, per unit area; $\mathrm{kg} \mathrm{DM} \mathrm{ha}^{-1}$ ) at time $\mathrm{t}$ (days), $\mathrm{SR}_{\mathrm{O}}$ is the initial mass of surface residue $\left(\mathrm{kg} \mathrm{DM} \mathrm{ha}^{-1}\right)$, and $k$ the actual decomposition rate coefficient $\left(\right.$ day $\left.^{-1}\right)$.

Soil coverage by the remaining crop residues is then described using the following equation [12, 23]:

$$
\mathrm{FSC}=1-\exp (-\beta \mathrm{SR})
$$

where FSC is the fraction of soil surface covered by crop residues and $\beta$ the area covered per unit dry weight of residue (ha $\left.\mathrm{kg}^{-1} \mathrm{DM}\right)$. The equation accounts for clumping and mutual shading by pieces of crop residues on the soil surface. The value of $\beta$ depends on the type of residue.

\subsubsection{Rainfall interception}

The maximum amount of water that can be retained by crop residues (SRWSAT, $\mathrm{mm}$ ) is proportional to the mass of the residues:

$$
\operatorname{SRWSAT}=\delta \text { SR } 10^{-4}
$$

where $\delta$ is the specific water retention capacity of the crop res-

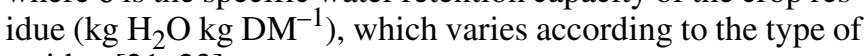
residue $[21,23]$.

The maximal amount of rainfall that can be intercepted by the layer of surface residue $\left(\mathrm{INR}_{\max }, \mathrm{mm}\right)$ at a given time is accordingly defined by the amount of water currently held (SRW, mm) and SRWSAT:

$$
\mathrm{INR}_{\text {max }}=\mathrm{SRWSAT}-\mathrm{SRW} .
$$

The actual amount of intercepted rainfall by surface residue $\left(\mathrm{INR}_{\mathrm{a}}, \mathrm{mm}\right)$ is a function of the fraction of soil covered by crop residues (FSC), limited by $\mathrm{INR}_{\max }$ :

$$
\mathrm{INR}_{\mathrm{a}}=\min \left[\mathrm{RAINS} \text { FSC, } \mathrm{INR}_{\text {max }}\right]
$$

where RAINS is the rainfall amount on the surface residue (mm), corrected for losses through interception by the crop canopy and water runoff.

\subsubsection{Soil and mulch evaporation}

Evaporation from soil is calculated based on the formalism developed by Ritchie [19]. There are two stages of soil evaporation: during the first stage the soil is wet enough for potential, energy-limited evaporation to occur, while during the second stage when the soil gets drier, the evaporation is lower depending on a climatic parameter and soil water availability (see for details Brisson et al. [5]). 
Potential soil evaporation is related to the energy available at the soil surface and is reduced in the presence of surface crop residue. The method of calculation corresponds to a Beer's law equivalent, where the radiation arriving at the soil surface through the layer of crop residues (Rss, $\mathrm{MJ} \mathrm{m}^{-2}$ ) is a function of the mulch area index (MAI):

$$
\text { Rss }=\mathrm{Ri} \times \exp (-\gamma \mathrm{MAI})
$$

where:

$$
\mathrm{MAI}=\beta \mathrm{SR}
$$

and $\mathrm{Ri}$ is the incident radiation arriving at the surface residue layer $\left(\mathrm{MJ} \mathrm{m}^{-2}\right)$ and $\gamma$ the extinction coefficient for net radiation in the surface residue layer.

Potential soil evaporation (Eos, mm day ${ }^{-1}$ ), is accordingly calculated as:

$$
\operatorname{Eos}=\mathrm{ETp} \exp (-\varepsilon \mathrm{LAI}) \exp (-\gamma \mathrm{MAI})
$$

where ETp is the reference evapotranspiration $\left(\mathrm{mm} \mathrm{day}{ }^{-1}\right)$, LAI the leaf area index, and $\varepsilon$ the extinction coefficient for net radiation in the crop canopy layer.

All the water held by surface residue is assumed to evaporate in proportion to the energy incident upon the surface residue layer. Accordingly, the direct potential evaporation from the mulch of crop residue (Eom, mm day ${ }^{-1}$ ) is calculated as:

$$
\text { Eom }=\mathrm{ETp} \exp (-\varepsilon \mathrm{LAI})[1-\exp (-\gamma \mathrm{MAI})]
$$

\subsubsection{Surface water runoff}

Water runoff (ROFF, $\mathrm{mm} \mathrm{day}^{-1}$ ) is calculated according to a simple empirical relationship, that relates runoff to the amount of rainfall (RAIN, mm day ${ }^{-1}$ ):

$$
\begin{array}{ll}
\mathrm{ROFF}=b(\mathrm{RAIN}-a) & \text { for RAIN }>a \\
\mathrm{ROFF}=0 & \text { for RAIN } \leq a
\end{array}
$$

where the empirical parameters $a\left(\mathrm{~mm} \mathrm{day}^{-1}\right)$ and $b$, respectively, denote the threshold value of rainfall below which there is no water runoff and the proportion of water above the threshold value that is lost through runoff. It is clear that $a$ and $b$ largely depend on the slope, texture, porosity and surface roughness of the soil. The effects of a mulch layer of crop residues on surface water runoff are accounted for by replacing the values of $a$ and $b$ for bare soil with those obtained for mulched soil (see below).

\subsection{Site and experiment descriptions}

We used data from two experimental sites with maize (Zea mays L.) cropping for the model testing and application. One site was located in La Tinaja, Mexico $\left(19^{\circ} 42^{\prime} \mathrm{N}, 103^{\circ} 47^{\prime} \mathrm{W}\right.$, $1200 \mathrm{~m}$ altitude), the other in Planaltina, Brazil $\left(15^{\circ} 35^{\prime} \mathrm{S}\right.$, $47^{\circ} 42^{\prime} \mathrm{W}, 1100 \mathrm{~m}$ altitude). The sites represent contrasting conditions of tropical environments (Fig. 1). The La Tinaja site has a semi-arid tropical steppe climate whereas the climate of Planaltina is a humid tropical of savannah type. Mean annual rain-
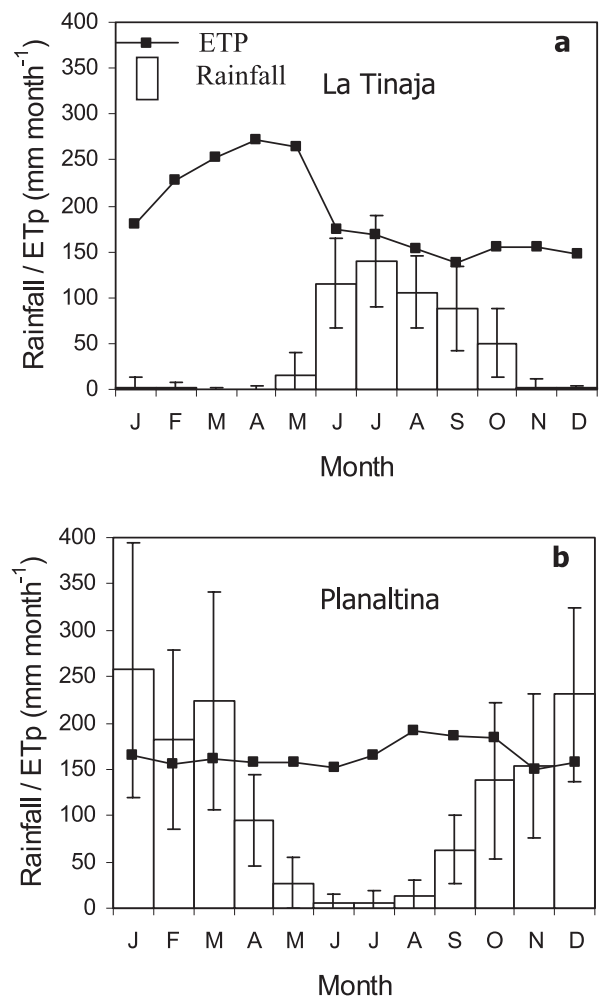

Figure 1. Monthly mean rainfall and reference Penman evapotranspiration for (a) La Tinaja and (b) Planaltina. Bars indicate standard deviation of means for 1992-2002 data in La Tinaja and 1973-2002 data in Planaltina.

fall in La Tinaja is $525 \mathrm{~mm}$ with 80 to $90 \%$ of the rain occurring between June and September. Dry spells of 10 days or longer are, however, common during the rainy season. Mean annual reference evapotranspiration in La Tinaja is about $1710 \mathrm{~mm}$ and the mean temperature during the growing season is around $25^{\circ} \mathrm{C}$. In Planaltina, mean annual rainfall is $1400 \mathrm{~mm}$, with a dry season from May until September. Reference evapotranspiration is fairly constant throughout the year with a mean annual total of $1480 \mathrm{~mm}$. The mean maximum and minimum temperatures during the growing season are 17 and $27{ }^{\circ} \mathrm{C}$, respectively.

The experiment in La Tinaja was carried out during the 1995 and 1996 growing seasons on a silty-loam soil (Dystric Cambisol) with the following treatments: (i) maize under conventional tillage (CT); (ii) maize directly seeded, but without a mulch of crop residues (DMC0); (iii) maize directly seeded into a residue mulch of $1.5 \mathrm{Mg}$ dry weight $\mathrm{ha}^{-1}$ (DMC1.5); (iv) maize directly seeded into a residue mulch of $3 \mathrm{Mg} \mathrm{ha}^{-1}$ (DMC3), and (iv) maize directly seeded into a mulch of $4.5 \mathrm{Mg}$ $\mathrm{ha}^{-1}$ (DMC4.5). In the CT treatment the soil was disked twice to a depth of about $10 \mathrm{~cm}$ before sowing the maize crop (cultivar HV 313) on 28/06/96. The mulch in the DMC treatments consisted of maize harvest residues from the previous cropping year. In each treatment, soil water content was monitored using a neutron meter at selected times during the growing season. 
Maximum LAI was estimated from radiation flux measurements with a Picqhélios $®$ radiometer at flowering, and final grain yield and total above-ground dry matter were determined during harvest (10/11/96). The field experiment in Planaltina was conducted during the 2001/2002 growing season at the experimental farm of Embrapa Cerrados on a Geri-Gibbsic Ferralsol (Xanthic) with a clayey texture, a widely distributed soil in the Cerrados. Maize (cultivar Cargil 125) was grown with CT practices and with direct seeding into mulch (DMC). In the CT treatment the soil was disked to about $20-\mathrm{cm}$ depth on 3 occasions before sowing the maize crop on $05 / 11 / 01$. In the DMC treatment a millet cover crop (sown on 02/04/01) preceded the maize crop. The millet was desiccated on 18/10/01 with glyphosate and laid down with a rolling harrow. The maize was directly seeded (05/11/01) in the resulting mulch (about $4 \mathrm{Mg} \mathrm{DM} \mathrm{ha}{ }^{-1}$ ) without any tillage operation. In both treatments soil moisture was monitored using a neutron probe and LAI was measured using a LICOR 2000 at regular intervals during the growing season. During harvest (15/03/02), the final grain yield and total above-ground dry matter of the maize crop were determined.

\subsection{Model parameterisation and simulations}

We first parameterised the model for the two sites, then examined the sensitivity of the model output to selected parameters of the surface residue module, and finally, quantified, using long-term climate records, the impact of surface residue management on crop production risk associated with rainfall variability at both sites.

Non-site-specific model parameters were those from an earlier calibration of STICS for maize growth under tropical conditions [1]. Cultivar- and site-specific plant parameters were obtained for each site by fitting the model to observed data on crop phenology and growth (see below). The data necessary to complete the model input files containing soil and management parameters were obtained from the respective experiments. Daily values for minimum and maximum temperature, radiation, wind speed and relative humidity were obtained from automatic weather stations, located in close proximity (less than $2 \mathrm{~km}$ ) to each experimental site. Daily rainfall was recorded on the experimental plots. The surface water runoff formalism (Eq. (10)) was calibrated by developing an empirical relationship between runoff and rainfall for each residue treatment. For the La Tinaja site, data from runoff plots established at the experimental site during the 1995 growing season were used [22]. For the Planaltina site, parameter values for surface runoff were estimated based on measured data from a runoff experiment at Goiania $\left(16^{\circ} 28^{\prime} \mathrm{S}, 49^{\circ} 17^{\prime} \mathrm{W}\right)$ comparing CT and DMC treatments on a Ferralsol under climatic and site conditions similar to those of Planaltina [4]. Finally, values for the parameters of the surface residue module (Eqs. (1-9)) were based on physical characteristics of the maize (La Tinaja) and millet (Planaltina) mulch measured during the respective experiments (for methodology see Scopel et al. [22]). A list of selected model parameters with their values is given in Table I.

A simple sensitivity analysis was performed to assess the relative importance of the three components (runoff, rainfall interception and radiation interception) of the surface residue module. We therefore tested the model's sensitivity in prediction of long-term average grain yield to the following key parameters of the module: (i) the surface runoff coefficients $a$ and $b$, (ii) the specific water retention capacity of the crop residue, $\delta$, and (iii) the extinction coefficient for net radiation in the surface residue layer, $\gamma$. The parameters influence, respectively: (i) the amount of water lost through surface runoff, (ii) the rainfall intercepted by surface residue and the direct evaporation from the residue mulch, and (iii) the reduction of soil evaporation by surface residue. For these simulations we used long-term temperature and rainfall data (25 yrs in Tinaja and 30 yrs in Planaltina), that were available from nearby weather stations. Longterm (30 yrs) daily radiation and reference Penman evapotranspiration data were also available for Planaltina, but for $\mathrm{La}$ Tinaja we used each year the same daily average values based on observations over a 4-year period (1994-1997) at the location. On a decadal basis, radiation and reference Penman evapotranspiration showed little variation between years at this site. All simulations were run with the values for other parameters than $a, b, \delta$ and $\gamma$ as those were obtained by calibrating the model at each site (see Tab. I), except for the value of RUE (4.2 $\mathrm{g} \mathrm{MJ}^{-1}$ [5]) in Planaltina that was increased to represent optimal growing conditions [1], which were not obtained in the experiment. Finally, as part of the sensitivity analysis, the effects of rainfall and radiation interception by surface residue were further examined by running the model for three levels of surface residue $\left(0,1\right.$ and $\left.6 \mathrm{Mg} \mathrm{ha}^{-1}\right)$ at both sites. For simplicity, we assumed in these simulations equal water runoff for the three residue levels $\left(a=5 \mathrm{~mm} \mathrm{day}^{-1}\right.$ and $\left.b=0.2\right)$ with values for $\delta$ and $\gamma$ from Table I.

To quantify the impact of crop residue mulching on water use and maize yield likelihood for a range of management and soil conditions at both sites, we simulated using long-term weather records yield sequences for a typical local maize cultivar for three sowing dates (early, medium and late) and two soil depths (low and high plant-available soil water storage capacity) and examined the interactions with three levels of surface residue (no mulch, and low and high quantity). Other model parameter values were the same as those described above (Tab. I). This resulted in a simulation matrix of 36 combinations (Tab. II). Simulated yields for each combination were sorted into ascending order and the cumulative distribution function (CDF) was calculated. To simplify presentation, only the minimum, 25, 50 (median) and 75 percentiles and maximum values of the CDFs were presented in bar form.

\section{RESULTS}

\subsection{Model parameterisation}

Figure 2 shows the empirical runoff-rainfall relationships for the CT and DMC treatments at both sites. The results clearly indicate a mulch effect on surface water runoff. In La Tinaja, residue mulching only had an effect on parameter $b$ (Eq. (10a), Fig. 2a), while in Planaltina mulching affected the value of both parameters $a$ and $b$ (Fig. 2b). In La Tinaja, increased amounts of surface residue reduced runoff with the value of $b$ decreasing from 0.54 (CT, no mulch) to 0.28 (DMC1.5, $1.5 \mathrm{Mg} \mathrm{ha}^{-1}$ ) and 0.18 (DMC4.5, $4.5 \mathrm{Mg} \mathrm{ha}^{-1}$ ). 
Table I. Values for selected parameters in STICS for maize growth at the two study sites.

\begin{tabular}{|c|c|c|c|c|}
\hline Parameter (units) & La Tinaja & Source & Planaltina & Source \\
\hline \multicolumn{5}{|l|}{ Surface residue layer $^{\mathrm{a}}$} \\
\hline$k\left(\right.$ day $\left.^{-1}\right)$ & 0.007 & observed, [23] & 0.007 & observed, [16] \\
\hline$\beta\left(\right.$ ha kg $\left.{ }^{-1} \mathrm{DM}\right)$ & 0.00037 & observed, [23] & 0.00039 & observed, [16] \\
\hline$\delta\left(\mathrm{kg} \mathrm{H}_{2} \mathrm{O} \mathrm{kg}{ }^{-1} \mathrm{DM}\right)$ & 3.8 & observed, [23] & 3.2 & observed, [16] \\
\hline$\gamma(-)$ & 0.80 & observed, [23] & 0.45 & observed, [16] \\
\hline \multicolumn{5}{|l|}{ Surface runoff } \\
\hline$a\left(\mathrm{~mm} \mathrm{day}^{-1}\right)$ & $\begin{array}{l}5(\mathrm{CT}) \\
5(\mathrm{DMC} 1.5) \\
5(\mathrm{DMC} 4.5)\end{array}$ & observed, [22] & $\begin{array}{l}10(\mathrm{CT}) \\
20(\mathrm{DMC})\end{array}$ & observed \\
\hline$b(-)$ & $\begin{array}{l}0.54 \text { (CT) } \\
0.28 \text { (DMC1.5) } \\
0.18 \text { (DMC4.5) }\end{array}$ & observed, [22] & $\begin{array}{l}0.35(\mathrm{CT}) \\
0.20 \text { (DMC) }\end{array}$ & observed \\
\hline \multicolumn{5}{|l|}{ Plant } \\
\hline$\varepsilon(-)$ & 0.7 & {$[1,5]$} & 0.7 & {$[1,5]$} \\
\hline DLAIMAX $\left(\mathrm{m}^{2}\right.$ leaves $\left.\mathrm{m}^{-2}{ }^{\circ} \mathrm{Cdays}^{-1}\right)$ & $1.25 \times 10^{-3}$ & fitted & $1.8 \times 10^{-3}$ & fitted \\
\hline $\operatorname{RUE}\left(\mathrm{g} \mathrm{DM} \mathrm{MJ} \mathrm{J}^{-1}\right)$ & 3.8 & fitted & $2.9^{\mathrm{b}}$ & fitted \\
\hline $\begin{array}{l}\text { VITIRCARB } \\
\left({\text { g grain } \mathrm{g}^{-1} \text { plant day }}^{-1}\right)\end{array}$ & 0.012 & fitted & 0.0125 & fitted \\
\hline E_A $\left({ }^{\circ} \mathrm{C}\right.$ days $)$ & 865 & fitted & 930 & fitted \\
\hline A_GF $\left({ }^{\circ} \mathrm{C}\right.$ days $)$ & 395 & fitted & 380 & fitted \\
\hline $\mathrm{Kc}_{\max }(-)$ & 1.2 & {$[5]$} & 1.4 & {$[1]$} \\
\hline \multicolumn{5}{|l|}{ Soil } \\
\hline PAWC (mm) & 140 & observed & 180 & observed \\
\hline $\mathrm{RD}(\mathrm{cm})$ & 120 & observed & 180 & observed \\
\hline $\mathrm{Q} 0(\mathrm{~mm})$ & 9 & $\begin{array}{l}\text { determined by soil texture } \\
\text { [5] }\end{array}$ & 6 & $\begin{array}{l}\text { determined by soil texture } \\
\text { [5] }\end{array}$ \\
\hline
\end{tabular}

a Mulch of maize harvest residues in La Tinaja and mulch of millet crop residues in Planaltina;

${ }^{\mathrm{b}} \mathrm{RUE}=4.2 \mathrm{~g} \mathrm{DM} \mathrm{MJ}^{-1}$ [5] for optimal growing conditions in Planaltina (in sensitivity and climatic risk simulations).

Table II. Summary of the soil and management options for the climatic risk simulations in La Tinaja and Planaltina.

\begin{tabular}{lll}
\hline & La Tinaja & Planaltina \\
\hline Sowing date (3) & $20 / 6,10 / 7,30 / 7$ & $18 / 9,18 / 10,18 / 11$ \\
PAW storage capacity (2) & $70,140 \mathrm{~mm}$ & $90,180 \mathrm{~mm}$ \\
Surface residue level (3) & $0,1,3 \mathrm{Mg} \mathrm{ha}^{-1}$ & $0,1,6 \mathrm{Mg} \mathrm{ha}^{-1}$ \\
\hline
\end{tabular}

Observed and simulated plant-available soil water (PAW, $0-120 \mathrm{~cm}$ soil depth) and LAI for the CT, DMC1.5 and DMC4.5 treatments in the La Tinaja experiment are shown in Figure 3. In these simulations, the number of thermal degree days from emergence to flowering (E_A), and from flowering to the beginning of grain filling (A_GF) were manually adjusted until the phenology was accurately simulated for the cultivar used. The maximum rate of LAI development (DLAIMAX) was calibrated to $1.2510^{-3} \mathrm{day}^{-1}$ (Tab. I) in order to fit the model output to the observed data of maximum LAI. The model predicted slightly larger and more prolonged maximum LAI with increased quantity of surface residue (Fig. 3). This is because the residue treatments had a significant effect on PAW, both measured and simulated, which resulted in dissimilar water stress on LAI between surface residue treatments. The course of PAW was simulated reasonably well for the DMC1.5 and DMC4.5 treatments, although the model slightly underestimated rates of soil water recharge after important rainfall events, and of water depletion during drier periods (Fig. 3b and c). In contrast, in the CT treatment, the model substantially underestimated dynamics of soil water recharge and depletion, as indicated by the discrepancy between observed and simulated PAW in that treatment (Fig. 3a). Observed and simulated PAW (0-180 cm soil depth) and LAI for both CT and DMC treatments in the Planaltina experiment are shown in Figure 4. Again, we calibrated the model for the observed phenological stages of the cultivar and fitted maximum LAI to the observed value by adjusting DLAIMAX $\left(1.8 \times 10^{-3} \mathrm{day}^{-1}\right)$. This resulted in a good fit for CT, but overestimated LAI in the case of the DMC treatment, especially for the latter sampling date. In fact, while the model predicted a slight increase in LAI with application of surface residue, the observed data indicated similar or even lower LAI values (latest sampling date) for DMC compared with CT. Once fitted to LAI, the model simulated well the observed course of PAW in the CT treatment (Fig. 4a). For DMC, the overestimation of LAI during the later stage of the 

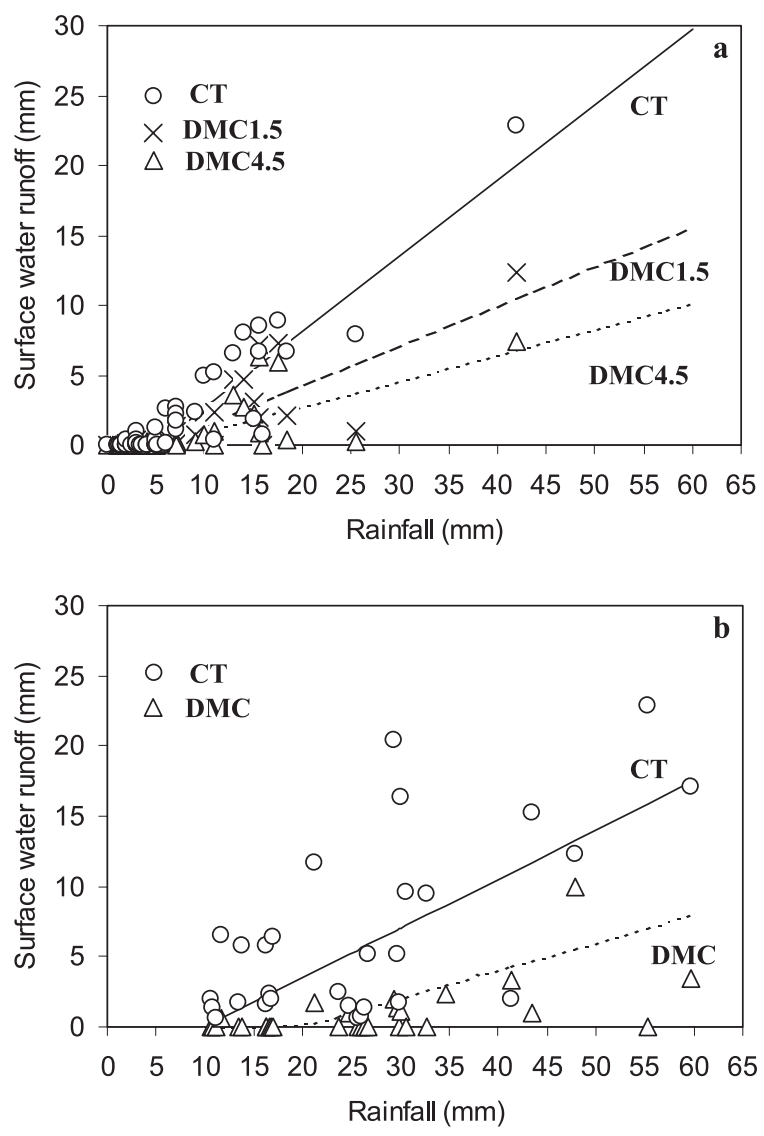

Figure 2. Relationship between surface water runoff and rainfall amount (a) for CT, DMC1.5 and DMC4.5 treatments in La Tinaja and (b) for CT and DMC treatments in Planaltina. Symbols are observed data and lines are the fitted relationships used in STICS. For La Tinaja, observations were made in runoff plots cropped with maize during the 1995 growing season on the La Tinaja site [22]; for Planaltina, observed data came from runoff plots with maize during the 2001/2002 growing season on a representative site in Goiãnia.

growing cycle clearly overvalued water consumption (Fig. 4b). Apart from this, the model over-predicted soil water content early in the growing season, possibly due to an overestimation of water conservation by the mulch of surface residues. In contrast to La Tinaja, observed PAW contents at the Planaltina site did not show mulch effects of soil water conservation. In the same way, simulated PAW dynamics were comparable for both the $\mathrm{CT}$ and DMC treatments, except during the first phase (from day 0 to 25) of soil water recharge.

The model was also fitted to observed data on final grain yield and total above-ground biomass for both sites by adjusting the parameters of radiation-use efficiency (RUE) and allocation to grain (VITIRCARB) (see Tab. I for parameter values). With these parameter adjustments we took into account possible genotype differences and sub-optimal growing conditions other than temperature or water stress. Figure 5 shows observed and simulated data for the five soil management treatments in the experiment in La Tinaja during two cropping seasons (1995
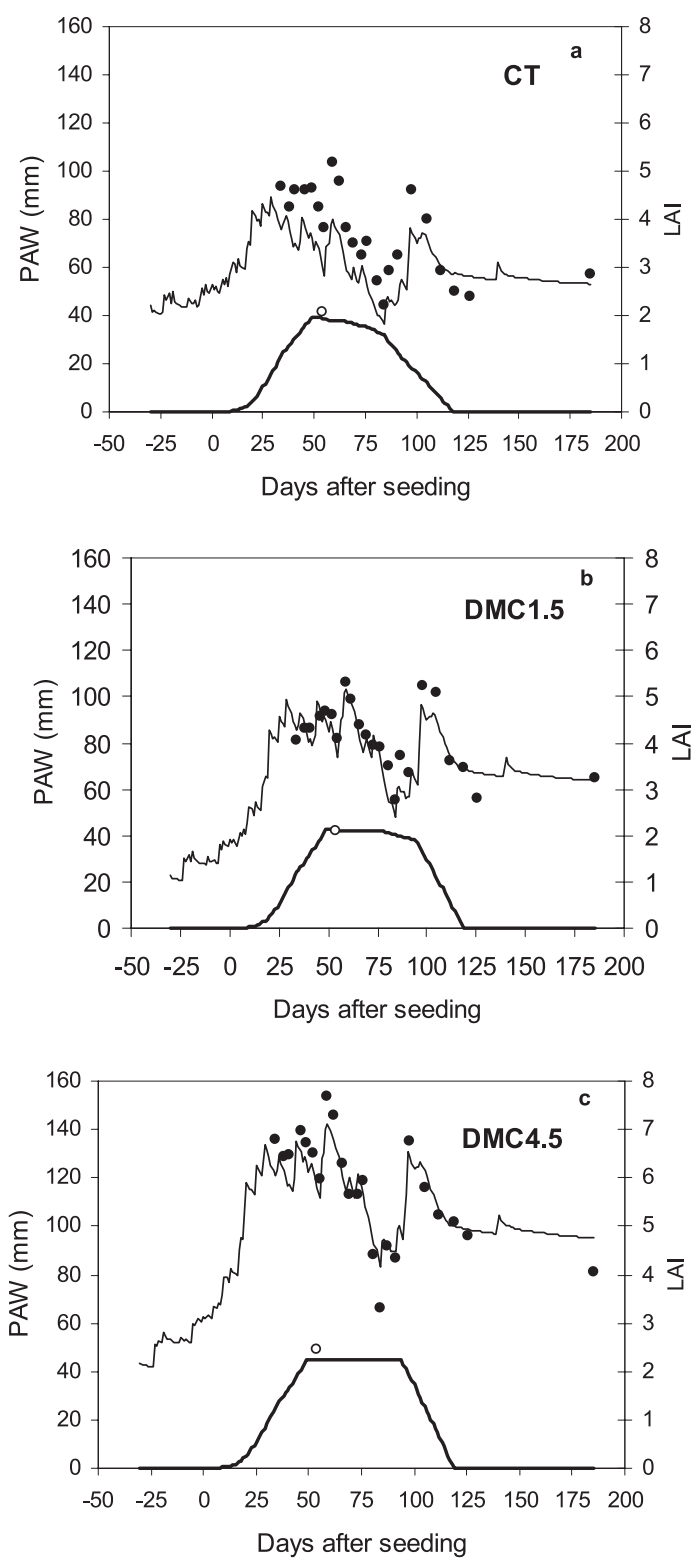

Figure 3. Observed (symbols) and simulated (line) PAW $(\bullet)(0$ $120 \mathrm{~cm}$ ) and maize LAI $(\mathrm{O})$ for three surface residue management treatments during the 1996 growing season in La Tinaja.

and 1996). Grain yield and total above-ground biomass were simulated well for all treatments over the two cropping years, with the slope and the intercept of the regressions not significantly $(P<0.01)$ different from the $1: 1$ line.

\subsection{Sensitivity analysis}

The relative importance of the three components (runoff, rainfall interception and radiation interception) of the surface residue module was examined through an analysis of the model's sensitivity in prediction of the final maize grain yield to the parameters $a$ and $b, \delta$ and $\gamma$. 

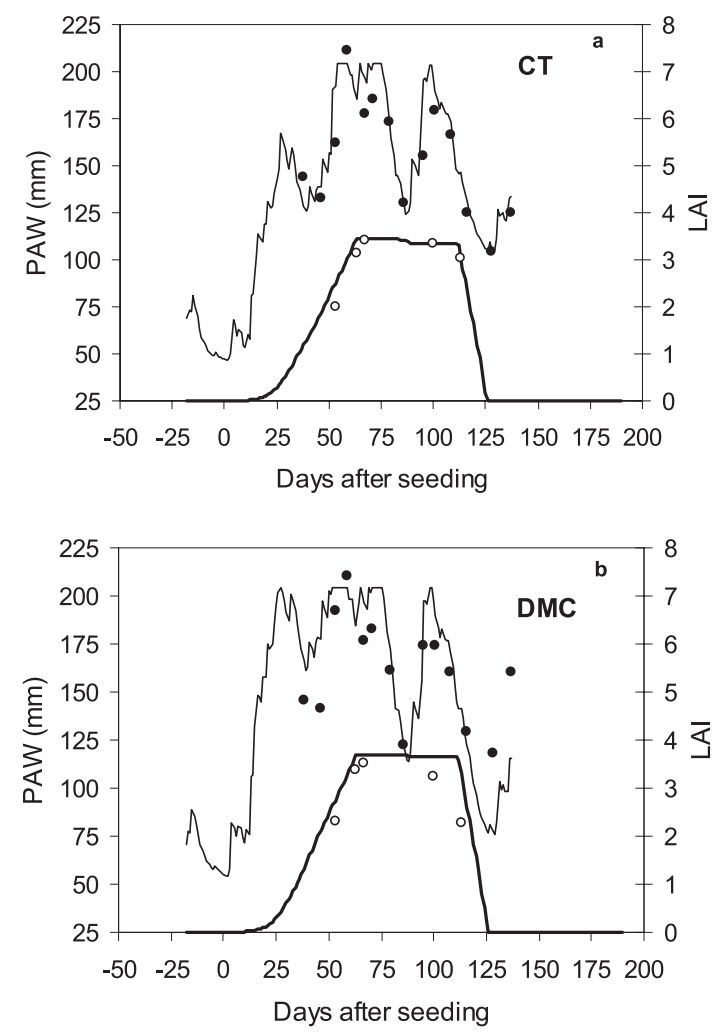

Figure 4. Observed (symbols) and simulated (line) PAW (•) (0$180 \mathrm{~cm})$ and maize LAI $(O)$ for two surface residue management treatments during the 2001/2002 growing season in Planaltina.

Figure 6 shows the grain yield responses at both sites to varying water runoff coefficients $a$ and $b$ (see Eq. (10)). In these simulations, $\delta$ and $\gamma$ were assumed to be zero (i.e. no effects of rainfall and radiation interception by mulch), which exclusively demonstrated the impact of changing runoff on grain yield. The parameters $a$ and $b$ are interactive: the effect of parameter $b$ becomes more significant with lower values for the threshold parameter $a$. For example, in Planaltina grain yield decreased only by about $10 \%$, when $b$ increased from 0 to 0.5 for a $10 \mathrm{~mm} \mathrm{day}^{-1}$ threshold $a$ value, whereas the same increase in $b$ caused a yield reduction of around $50 \%$ when $a$ was set to zero. For the same changes in parameter values, yield responses were relatively greater in La Tinaja compared with Planaltina. This is because of the more water-limiting conditions in $\mathrm{La}$ Tinaja. Simulated grain yield response to runoff in Planaltina was 'buffered' through the mechanism of increased drainage loss with decreased runoff. The model predicted for the Planaltina site that decreasing runoff by $100 \mathrm{~mm}$ resulted in a corresponding increase of $60 \mathrm{~mm}$ in the drainage (data not shown). In contrast, drainage losses in La Tinaja were small to zero and decreased runoff is largely $(>70 \%)$ accounted for by an increase in transpiration (data not shown).

The effects of rainfall and radiation interception by surface residue (parameters $\delta$ and $\gamma$ ) are illustrated in Figure 7, where simulated grain yield is shown as a function of surface water runoff for different sets of values of $\delta$ and $\gamma$. In fact, by assigning
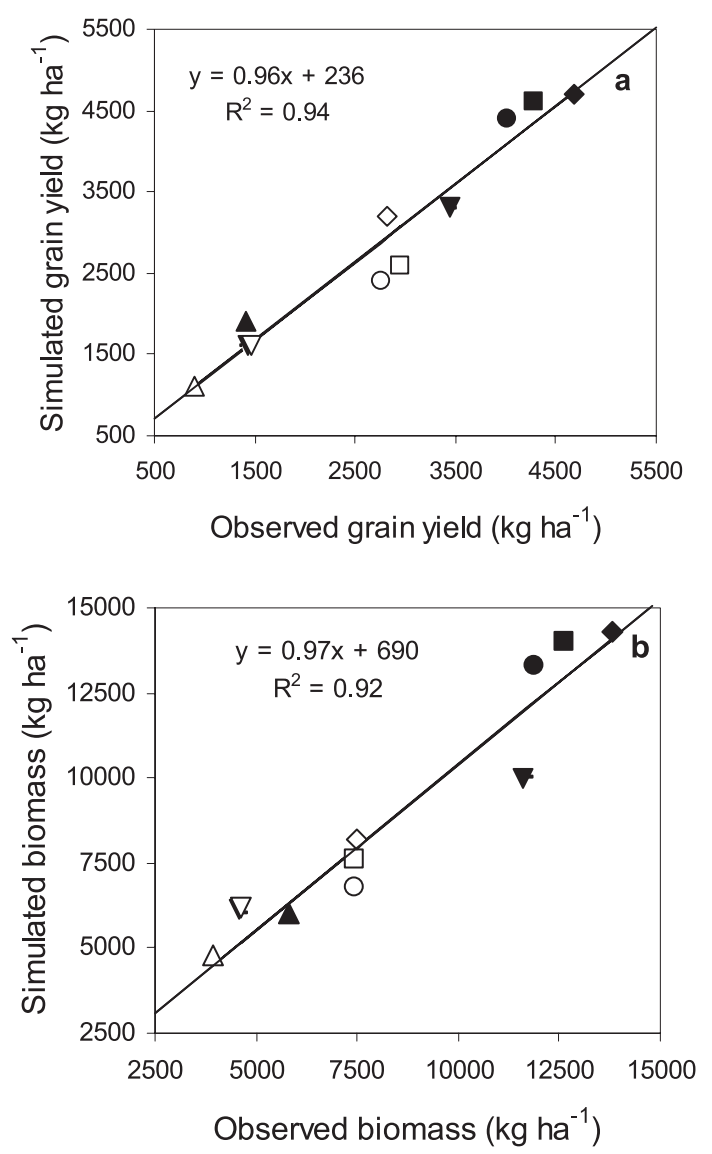

Figure 5. Simulated versus observed values for (a) grain yield and (b) total above-ground biomass of maize grown during the 1995 (white symbols) and 1996 (black symbols) growing seasons in the La Tinaja site. The five points per growing season represent the five treatments $(\nabla \nabla \mathrm{CT}, \triangle \Delta \mathrm{DMC} 0, \bigcirc \bullet \mathrm{DMC} 1.5, \square \mathrm{DMC} 3$ and $\diamond$ - DMC4.5) of the experiment (see text).

a zero value to $\delta$ and $\gamma$, respectively, the mechanisms of rainfall and radiation interception are switched off in the model. The value of 1.0 for $\gamma$ is the theoretical value for randomly distributed, horizontal, black elements. For these simulations we assumed for both sites an initial surface residue level of $6 \mathrm{Mg}$ $\mathrm{ha}^{-1}$. Varying amounts of surface runoff were obtained by running the model with changing values for parameter $b$. Between $\gamma=1$ (maximum radiation interception by surface residue) and $\gamma=0$ (no radiation interception) and with $\delta=5$, the simulated decline in grain yield was between $25 \%$ and $80 \%$ in La Tinaja and between $5 \%$ and $35 \%$ in Planaltina, depending on the runoff losses (Fig. 7). As expected, the mulch effect of radiation interception on final yield was closely related to soil water supply to the plant, as the effect is to reduce soil evaporation. By decreasing $\delta$ from $\delta=5$ (maximum value for specific water retention capacity of residue) to $\delta=0$ (no interception of rainwater by mulch) and with $\gamma=1$, simulated grain yield increased by between 10 and $55 \%$ in La Tinaja and between 2 and $15 \%$ in Planaltina, again depending on surface water runoff. This is 


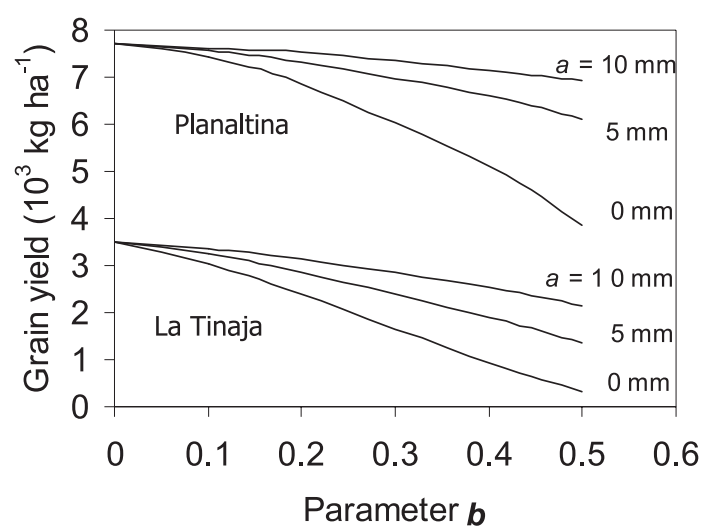

Figure 6. Simulated responses of grain yield to changing values of surface water runoff parameters $a$ and $b$. Simulations were run with parameters $\delta$ and $\gamma$ equal to zero.
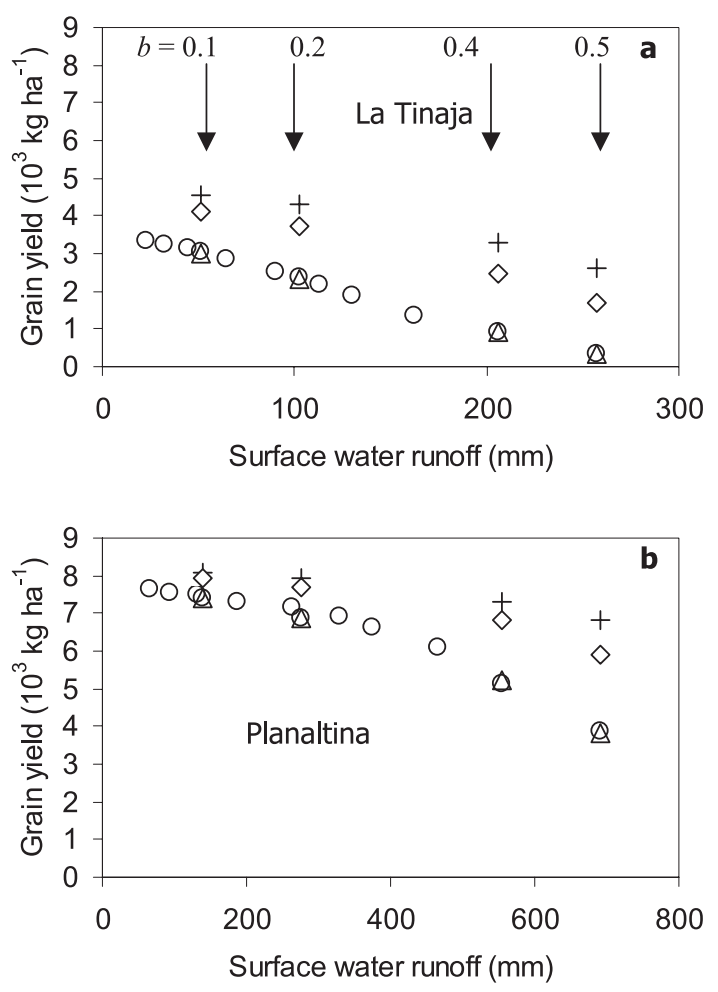

Figure 7. Simulated responses of grain yield as a function of surface water runoff to changing values of rainfall and radiation interception parameters $\delta$ and $\gamma$ in (a) La Tinaja and (b) Planaltina. (O) $\delta=0, \gamma=$ $0 ;(\Delta) \delta=5, \gamma=0 ;(+) \delta=0, \gamma=1 ;(\diamond) \delta=5, \gamma=1$. All simulations were run for a surface residue level of $6 \mathrm{Mg} \mathrm{ha}^{-1}$.

because water intercepted by surface residue evaporates rapidly at the first stage rate and is lost for plant uptake.

A comparison of results from model runs with varying levels of surface residue $\left(0,1\right.$ and $6 \mathrm{Mg} \mathrm{ha}^{-1}$, Tab. III) indicated that high levels of surface residue have a large impact on soil evaporation at both sites: the presence of $6 \mathrm{Mg} \mathrm{ha}^{-1}$ surface residue more than halved soil evaporation. However, a large part of this water gain (40\% in La Tinaja and $80 \%$ in Planaltina) was counterbalanced by evaporation loss from surface residue and, in the case of Planaltina, by increased drainage. The final effect was a $40 \%$ (La Tinaja) and 10\% (Planaltina) increase in transpiration and corresponding increase in grain yield. As expected, the effect of a low level of surface residue $\left(1 \mathrm{Mg} \mathrm{ha}^{-1}\right)$ was much smaller, with a decrease of about 10 to $15 \%$ in soil evaporation. Again, a large part of this (small) water gain (30\% in La Tinaja and $80 \%$ in Planaltina) was offset by evaporation from surface residue and drainage. The final gains in transpiration (and yield) with the retention of $1 \mathrm{Mg} \mathrm{ha}^{-1}$ surface residue predicted by the model were about $13 \%$ in La Tinaja and less than $3 \%$ in Planaltina.

\subsection{Climatic risk analysis}

In La Tinaja, surface residue management had a large impact on yield likelihood (Fig. 8). A crop residue mulch of $1 \mathrm{Mg} \mathrm{ha}^{-1}$ resulted in a strong increase in the 25,50 and 75 percentile yield values compared with the simulations with no mulch. The absolute increase in median grain yield with $1 \mathrm{Mg} \mathrm{ha}^{-1}$ surface residue varied between about $1000 \mathrm{~kg} \mathrm{ha}^{-1}$ (late sowing and low PAW storage capacity) and $1600 \mathrm{~kg} \mathrm{ha}^{-1}$ (late sowing and high PAW storage capacity). Over all combinations of sowing date and PAW storage capacity, median grain yield increased twoto four-fold with retention of $1 \mathrm{Mg} \mathrm{ha}^{-1}$ surface residue. The effect of an extra $2 \mathrm{Mg} \mathrm{ha}^{-1}$ surface residue was much smaller: averaged over all combinations, median grain yield only increased by about $500 \mathrm{~kg} \mathrm{ha}^{-1}$ when passing from 1 to $3 \mathrm{Mg}$ $\mathrm{ha}^{-1}$ surface residue (Fig. 8). The simulations also showed that delayed sowing (from 20/6 to 30/7) decreased yields at 25, 50 and 75 percentiles for all levels of surface residue. The absolute decrease in median yield was fairly small $\left(<300 \mathrm{~kg} \mathrm{ha}^{-1}\right)$ for sowing until 10/7 and tempered by the use of surface residue (25\% relative decline for zero mulch compared with $<10 \%$ decline for 1 and $3 \mathrm{Mg} \mathrm{ha}^{-1}$ residue levels). However, with a $30 / 7$ sowing the yield decline became more significant (for zero mulch a $65 \%$ yield decline compared with $20 / 6$ sowing) and the relative impact of surface residue was smaller for the $70-\mathrm{mm}$ PAW storage profile (still $40 \%$ decline) compared with the $180-\mathrm{mm}$ profile ( $25 \%$ decline).

In Planaltina, the highest median yield and lowest variability were predicted for an $18 / 10$ sowing with $6 \mathrm{Mg} \mathrm{ha}^{-1}$ surface residue (Fig. 9). However, the impact of surface residue management on maize yield likelihood was much smaller than in La Tinaja. For example, for early sowing (18/09), retention of $6 \mathrm{Mg} \mathrm{ha}^{-1}$ surface residue increased 25 percentile yield values by only about $700 \mathrm{~kg} \mathrm{ha}^{-1}$, and mulching effects on median values were even smaller $\left(<500 \mathrm{~kg} \mathrm{ha}^{-1}\right)$ and were almost zero on the 75 percentile yield values (Fig. 9). This indicates that crop residue mulching in Planaltina is mostly effective during years of low yield potential (low water supply). The simulations also showed that surface residue effects on yield likelihood were less pronounced with later sowing and even tended to completely disappear for an 18/11 sowing (Fig. 9). Compared with early sowing, medium and late sowing reduce yield variability, as indicated by the smaller range bars, and the effects of high PAW storage capacity become evident with later sowing.

As already mentioned above, surface residue management under the climatic conditions of Planaltina also has a major 
Table III. Simulated grain yield and water balance components for La Tinaja and Planaltina.

\begin{tabular}{|c|c|c|c|c|c|c|c|}
\hline Site & $\begin{array}{c}\mathrm{SR}_{\mathrm{o}} \\
\left(\mathrm{Mg} \mathrm{ha}^{-1}\right)\end{array}$ & $\begin{array}{c}\mathrm{Y} \\
\left(\mathrm{Mg} \mathrm{ha}^{-1}\right)\end{array}$ & $\begin{array}{c}\mathrm{T} \\
(\mathrm{mm})\end{array}$ & $\begin{array}{l}\text { Es } \\
(\mathrm{mm})\end{array}$ & $\begin{array}{l}\mathrm{Em} \\
(\mathrm{mm})\end{array}$ & $\begin{array}{c}\mathrm{R} \\
(\mathrm{mm})\end{array}$ & $\begin{array}{c}\mathrm{D} \\
(\mathrm{mm})\end{array}$ \\
\hline LT & 0 & $2.9(1.2)$ & $162(68)$ & $280(44)$ & $0(0)$ & $65(18)$ & $0(0)$ \\
\hline LT & 1 & $3.3(1.1)$ & $181(62)$ & $241(40)$ & $12(2)$ & $65(18)$ & $1(4)$ \\
\hline LT & 6 & $4.1(0.8)$ & $231(45)$ & $120(21)$ & $63(9)$ & $65(18)$ & $6(15)$ \\
\hline $\mathrm{P}$ & 0 & $7.3(1.2)$ & 337 (49) & $506(59)$ & $0(0)$ & $187(48)$ & 280 (187) \\
\hline $\mathrm{P}$ & 1 & $7.5(1.1)$ & $347(48)$ & $448(51)$ & $22(3)$ & $187(48)$ & 306 (194) \\
\hline $\mathrm{P}$ & 6 & $7.9(1.1)$ & $370(37)$ & $244(32)$ & $113(17)$ & $187(48)$ & $387(210)$ \\
\hline
\end{tabular}

LT: La Tinaja; P: Planaltina; $\mathrm{SR}_{\mathrm{o}}$ : initial mass of surface residue; Y: grain yield; T: transpiration; Es: soil evaporation; Em: evaporation from surface residue; R: runoff; D: drainage.

Means of simulated values using 25 (La Tinaja) and 30 (Planaltina) years rainfall data with $a=5 \mathrm{~mm} \mathrm{day}^{-1}, b=0.2, \delta=5, \gamma=1$, and with other model parameters the same as those in Table I. Values in parentheses are standard deviations of means.

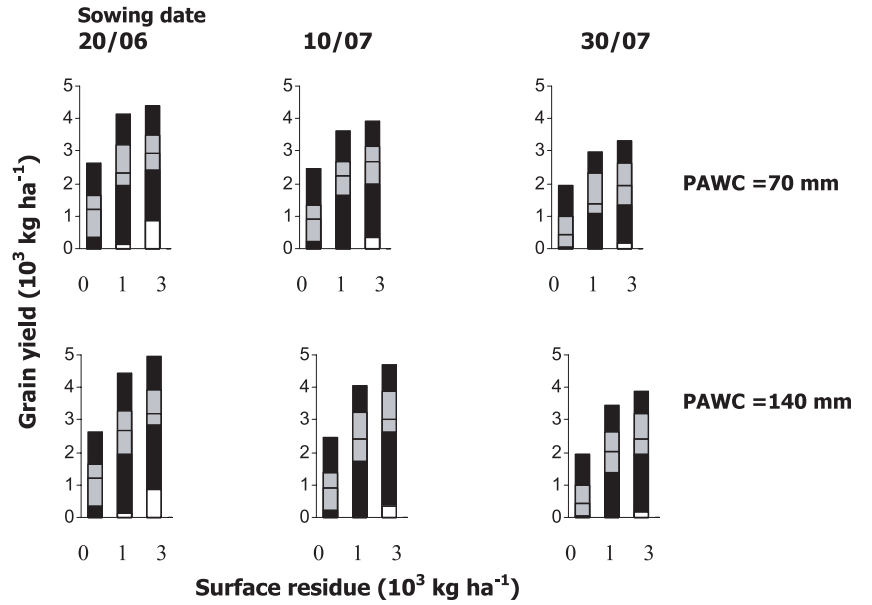

Figure 8. Effect of residue management, sowing date and PAW storage capacity on grain yield of maize in La Tinaja. The black/grey bars encompass the range between the minimum and maximum yield, the extremes on the grey bars encompass the range between the 25 and 75 percentiles and the horizontal line shows the median yield level. PAWC: plant-available soil water storage capacity.

impact on the risk of water drainage. As an example, the results of model simulations are shown for the soil with the high $(180 \mathrm{~mm})$ PAW storage capacity (Fig. 10). The model predicted for an 18/10 sowing an increase in median water drainage of around $150 \mathrm{~mm}$ (from about $470 \mathrm{~mm}$ to $620 \mathrm{~mm}$ ) with the retention of $6 \mathrm{Mg} \mathrm{ha}^{-1}$ surface residue. While drainage exceeded $570 \mathrm{~mm}$ in $25 \%$ of years for the zero mulch treatment, this level becomes $700 \mathrm{~mm}$ for a $6 \mathrm{Mg} \mathrm{ha}^{-1}$ surface residue. Similar results of surface residue effects on drainage were predicted for earlier and later sowing dates, with the difference that for late sowing the range of possibilities is extended to zero drainage (Fig. 10).

\section{DISCUSSION}

We updated the crop growth model STICS with a simple surface residue module in which three major mulch effects on

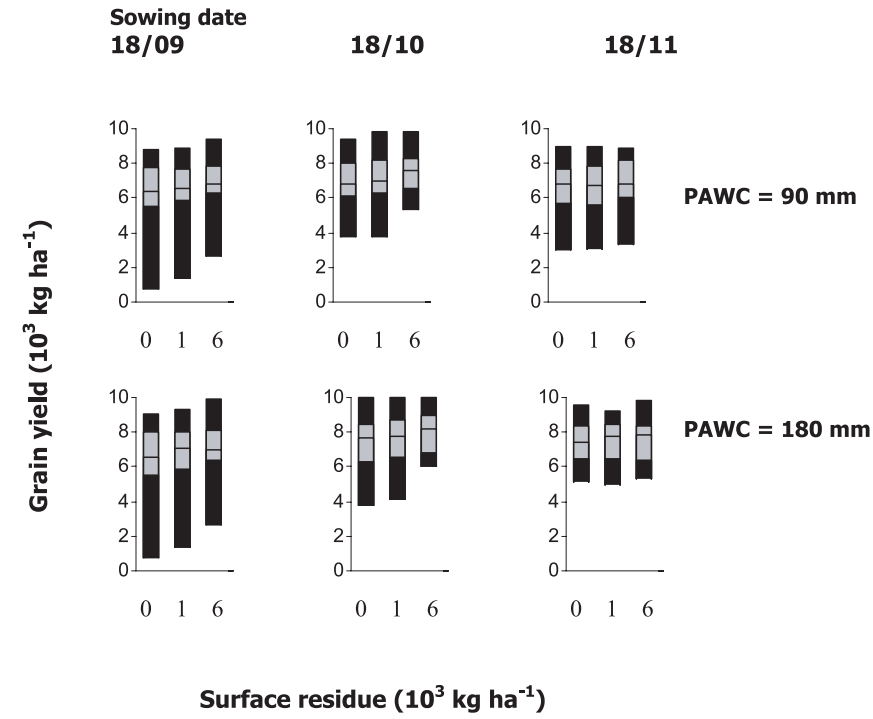

Figure 9. Effect of residue management, sowing date and PAW storage capacity on grain yield of maize in Planaltina. The black/grey bars encompass the range between the minimum and maximum yield, the extremes on the grey bars encompass the range between the 25 and 75 percentiles and the horizontal line shows the median yield level. PAWC: plant-available soil water storage capacity.

water balance are described by empirical functions: (i) rainfall interception, (ii) radiation interception modifying the dynamics of soil evaporation, and (iii) surface water runoff. The experiments used for model testing were, however, not set up to examine effects of surface residue on soil water balance components in depth. Our objective was not to validate all details of the surface residue module but to understand and quantify the main impacts of surface residue using a simple model approach, respectively, in tropical semi-arid Mexico and humid Brazil. This was possible with the simple modifications made to the model.

The effects of rainfall and radiation interception on soil water conservation by surface residue are counterbalancing 


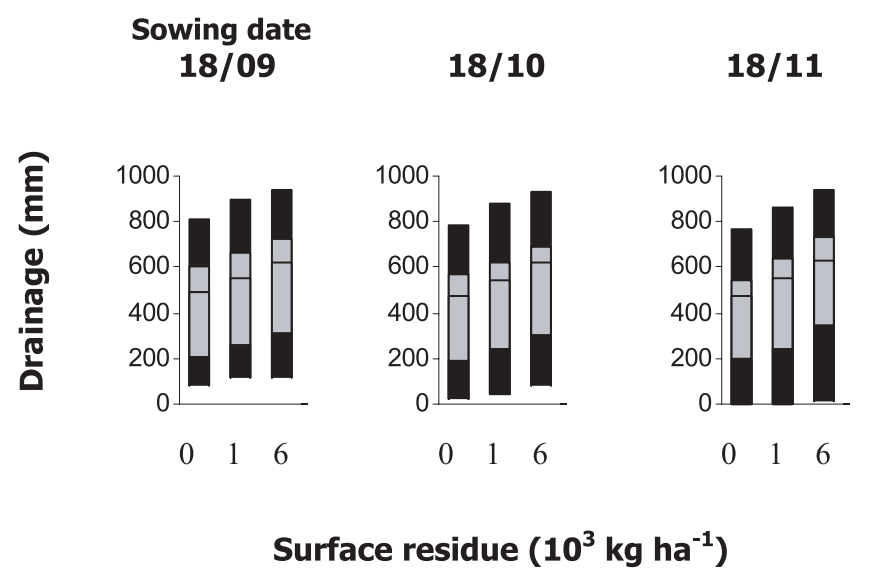

Figure 10. Effect of residue management and sowing date on drainage losses in Planaltina for a PAW storage capacity of $180 \mathrm{~mm}$. The black/grey bars encompass the range between the minimum and maximum yield, the extremes on the grey bars encompass the range between the 25 and 75 percentiles and the horizontal line shows the median yield level.

(Tab. III). Surface residue limits the energy reaching the soil surface, decreasing first-stage evaporation of soil water. On the other hand, a layer of surface residue can store an amount of water that then evaporates at the first stage rate. Our simulation results show that over the whole year the radiation effect is much more important for governing total evaporation than the effect of intercepting rain at both sites (Tab. III). The simulated reduction of soil evaporation by a residue mulch of $1 \mathrm{Mg} \mathrm{ha}^{-1}$ is about three times larger than the amount of water intercepted and subsequently evaporated from the mulch. With increased amounts of surface residue the effect of rainfall interception and subsequent mulch evaporation becomes relatively more important, but in absolute terms more water is conserved. It should also be noted that evaporation from the residue mulch layer is overestimated by the model, since it is assumed that it occurs at the first stage. The results suggest that if used for maximum control of evaporative water losses, high mulch loads are recommended for both sites. It is, however, not always possible to produce or to maintain high levels of crop residues. Moreover, other processes such as $\mathrm{N}$ immobilisation may limit plant growth when retaining high amounts of crop residues on the soil surface [28].

Our modelling approach thus consists of a simple quantitative description of surface residue effects on the water balance, requiring only limited data inputs. This is in contrast with other published more detailed, physically-based mulch models that quantify surface residue effects on soil water content by solving the balance of energy and water at the soil surface [7, 10, 20]. Parameterisation of such models for application to practical problems remains, however, difficult because measurements of the necessary parameters are not available for a wide range of conditions. Moreover, a large number of these parameters that are related to the physical properties of the mulch layer may evolve considerably in time due to decomposition, especially under the hot and humid conditions of the tropics [26]. Apart from the runoff coefficients (see below), our surface residue

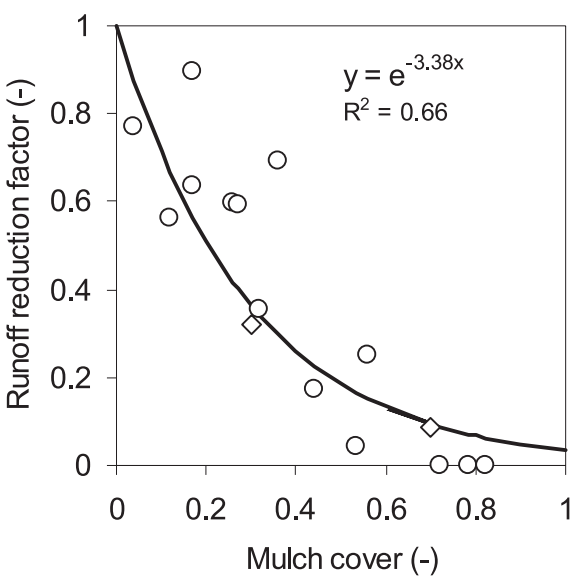

Figure 11. Relationship between surface residue cover and water runoff reduction factor. The reduction is relative to runoff from bare soil. Symbols are observed data from $(\bigcirc)$ Gilley et al. [11] and $(\diamond)$ Findeling et al. [10].

module requires only four mulch parameters (Tab. I). Two of those parameters $(\gamma$, the extinction coefficient and $\delta$, the specific water retention capacity of the mulch) have a direct influence on soil water balance processes. Given the extreme values we used for $\gamma$ and $\delta$ in the sensitivity analysis and the rather limited sensitivity of simulated yield to these parameters under runoff conditions of mulched soils (Fig. 7) as compared with the parameters related to runoff, the choice of these values is not too critical for model predictions and therefore it is reasonable to use 'nominal' values for $\gamma$ and $\delta$. There are few published values for $\gamma$. Wagner-Riddle et al. [29] reported a value of 0.98 for residues from rye, which is higher than the values measured in the experiments reported here (Tab. I). For $\delta$, published values range between 2 and $4.5 \mathrm{~kg} \mathrm{H}_{2} \mathrm{O} \mathrm{kg} \mathrm{DM}{ }^{-1}$ mulch [2, 21, $23,29]$.

The high sensitivity of model yield predictions to both surface runoff parameters $a$ and $b$, especially under the semi-arid conditions of the La Tinaja site (Fig. 6), highlights the importance of a careful parameterisation of the surface water runoff formalism. In the model, residue effects on surface runoff are considered by changing runoff coefficients with mulch level. For the Mexican site, the $b$ value changed from 0.54 (no mulch) to $0.28\left(1 \mathrm{Mg} \mathrm{ha}^{-1}\right.$ ) and 0.18 (4.5 $\left.\mathrm{Mg} \mathrm{ha}^{-1}\right)$ (Fig. 2). Surface residue, even at a low level, substantially reduces the runoff amount [10]. With the above $b$ values, and $a=5 \mathrm{~mm} \mathrm{day}^{-1}$ and all other parameters being equal between mulch treatments (Tab. I), simulated grain yield increased with $110 \%$ and $150 \%$ for, respectively, $1 \mathrm{Mg} \mathrm{ha}^{-1}$ and $4.5 \mathrm{Mg} \mathrm{ha}^{-1}$ surface residue compared with the zero mulch treatment (Fig. 6). These yield predictions were in agreement with observations (Fig. 5).

In our present model we did not incorporate explicit relationships describing mulch effects on surface runoff. It has been suggested that a partial residue mulch increases soil infiltration, as a result of (1) the increased flow path tortuosity and roughness, which slows down the water flow rate across the soil surface, and (2) the improved topsoil structure, mainly due to increased macro-fauna activity [10]. In the present model the 
amount of water lost through runoff was calculated based on empirical runoff coefficients for each site and surface residue treatment. This is a serious drawback of the model and makes the model highly site- and season-specific. For example, in La Tinaja much of the bias observed between measured and simulated PAW in the CT treatment (Fig. 3a) was probably caused by an overestimation of surface water runoff. The empirical runoff-rainfall relationships used (Fig. 2) were established during the 1995 growing season, when maize growth was smaller than in 1996. This suggests that the reducing effect of the plant canopy on water runoff was more significant in 1996 than in 1995. Moreover, it is expected that this plant canopy effect is relatively more important in the $\mathrm{CT}$ treatment without a mulch cover than in the DMC treatments with mulch. One way to address this shortcoming would be to estimate runoff for bare soil based on site characteristics (using the USDA Curve Number Method) and modify that through a relationship between soil cover and runoff reduction (where soil cover includes both the crop canopy and residue mulch layer). Figure 11 shows an example of a 'generic' relationship for the effect of residue mulch on surface runoff. The relationship is principally based on data from Gilley et al. [11], showing that water runoff is reduced exponentially as a function of the fraction of soil surface covered by crop residues. In a similar way, the effects of canopy cover could be approximated based on data from Findeling et al. [10] that suggest a $15 \%$ decrease in runoff per unit increase in LAI.

Management practices, climatic conditions and soil type may influence crop response to water conservation by surface residue. Our model analysis quantified the effects of surface residue management on maize grain yield likelihood associated with the probable range of climatic conditions at two locations with contrasting tropical weather (Planaltina in humid Brazil and La Tinaja in semi-arid Mexico) for different sowing dates and for soils with different PAW storage capacities (Figs. 8 and 9). The broad range in simulated yield associated with each combination, even at the humid Planaltina site, reflects the effect of the high variability in rainfall at both sites (Fig. 1). Differences in the impact of surface residue management and in yield probability between the two locations were largely related to the amount of rainfall. At the semi-arid location in Mexico, retention of surface residue at least doubled the median grain yield (Fig. 8). The greatest response to surface residue was from 0 to $1 \mathrm{Mg} \mathrm{ha}^{-1}$ with a smaller response to further increasing the mulch level (dependent on the soil water supply conditions). This suggests that even small amounts of surface residue are effective at reducing water loss and increasing yield. For the humid conditions in Brazil, the advantage of water conservation by surface residue was partly offset by increased drainage (Fig. 10; Tab. III). At this site evaporative demand is, in general, lower than rainfall during the growing season (Fig. 1). As a consequence, the impact of crop residue mulching on grain yield was small. The phenomenon of increased deep drainage under DMC compared with conventional cropping systems was observed in fields in the Cerrados by Lilienfein et al. [15]. Deep drainage induces a risk of nutrient leaching. The large pool of easily decomposable organic compounds from surface residues adds to the risk of nutrient leaching in DMC systems. Maintaining the soil profile below its water holding capacity, particularly during periods when rainfall probability is high, is therefore crucial to minimise both deep drainage and nutrient leaching. The results from our simulations highlight the importance of introducing cover crops in the cropping systems of the tropical humid environments to simultaneously minimise runoff and drainage below the root zone [24]. It is also evident that with a second crop total plant biomass increases and subsequent mulch effects on water conservation become more significant, especially in regions with a dry season such as the Cerrados.

Finally, DMC systems encompass several other features which were not considered in the present surface residue module. Most importantly, not tilling the soil and the increased biological activity due to mulching have effects on soil physical properties such as hydraulic conductivity and bulk density that may affect soil water balance processes. However, quantitative description of these effects is often incomplete and difficult to extrapolate for a particular location or soil type to a wide range of situations. One of the few examples of simulation models that predict soil physical properties in relation to soil management practices is reported by Andales et al. [2], who developed a 'tillage' model that predicts changes in bulk density and hydraulic conductivity as a function of cumulative rainfall kinetic energy. Besides, for a more comprehensive evaluation of DMC systems other effects on soil surface conditions also need to be included, such as mulch-induced changes in soil temperature and nutrient dynamics. An integrated representation of mulch and tillage effects in simulation models will enhance our understanding of DMC system functioning and will improve our capability of predicting the impact of DMC on productivity and sustainability.

\section{CONCLUSIONS}

We analysed the impact of surface crop residue on water use and production risk of maize for two tropical locations of contrasting climate using a modelling approach. A simple surface residue module was incorporated into the STICS crop growth model for this study. The results showed that under the semiarid conditions of La Tinaja in Mexico, where rainfall variability is high, even small amounts of surface residue are effective at reducing water loss (surface runoff and soil evaporation), giving rise to higher yields with smaller risks of crop failure. Under the humid conditions of the Cerrado region in Brazil, potential gains in water through a decrease in runoff and evaporation are largely offset by increased drainage losses with possible leaching of nutrients. As a consequence, under these climatic conditions the impact of crop residue mulching on grain yield in DMC systems is small and the use of cover crops as nutrient recyclers becomes crucial.

The model outputs are most sensitive to the empirical runoff coefficients of the surface water runoff formalism, emphasising the need for a careful site-specific parameterisation of the runoff-rainfall relationships for bare and mulched soils.

Obviously, for a more complete modelling analysis and agronomic evaluation of DMC systems, other effects of surface crop residues, such as nitrogen and organic matter contributions to the soil, also have to be considered. This is the subject of our ongoing research. 


\section{APPENDIX}

Table A1. Definitions of variables and parameters used.

\begin{tabular}{|c|c|c|}
\hline$\beta$ & surface area covered per unit dry weight of crop residue & ha $\mathrm{kg}^{-1} \mathrm{DM}$ \\
\hline$\gamma$ & extinction coefficient for net radiation in the surface residue layer. & - \\
\hline$\delta$ & specific water retention capacity of crop residue & $\mathrm{kg} \mathrm{H}_{2} \mathrm{O} \mathrm{kg}^{-1} \mathrm{DM}$ \\
\hline$\varepsilon$ & extinction coefficient for net radiation in the canopy layer & - \\
\hline $\mathrm{a}$ & threshold value of precipitation below which there is no water runoff & $\mathrm{mm} \mathrm{day}^{-1}$ \\
\hline$b$ & proportion of water above the threshold value that is lost through runoff & - \\
\hline$k$ & decomposition rate coefficient of crop residue & day $^{-1}$ \\
\hline A_GF & thermal duration from flowering to beginning of grain filling & ${ }^{\circ}$ Cdays \\
\hline DLAIMAX & maximum rate of LAI development & $\mathrm{m}^{2}$ leaves $\mathrm{m}^{-2}{ }^{\circ} \mathrm{Cdays}^{-1}$ \\
\hline E_A & thermal duration from emergence to flowering & ${ }^{\circ}$ Cdays \\
\hline Eos & potential soil evaporation & $\mathrm{mm} \mathrm{day}^{-1}$ \\
\hline Eom & direct potential evaporation from the surface crop residues & $\mathrm{mm} \mathrm{day}^{-1}$ \\
\hline ETp & Reference evapotranspiration & $\mathrm{mm} \mathrm{day}^{-1}$ \\
\hline FSC & fraction of soil surface covered by crop residues & - \\
\hline $\mathrm{INR}_{\mathrm{a}}$ & actual amount of intercepted precipitation by surface residues & $\mathrm{mm}$ \\
\hline $\mathrm{INR}_{\max }$ & maximal amount of rainfall that can be intercepted by surface residues & $\mathrm{mm}$ \\
\hline $\mathrm{Kc}_{\max }$ & maximum crop coefficient for water requirements & - \\
\hline LAI & leaf area index & $\mathrm{m}^{2}$ leaves $\mathrm{m}^{-2}$ \\
\hline MAI & mulch area index & $\mathrm{m}^{2}$ mulch $\mathrm{m}^{-2}$ \\
\hline PAW & plant-available soil water & $\mathrm{mm}$ \\
\hline PAWC & plant-available soil water storage capacity & $\mathrm{mm}$ \\
\hline RAIN & daily precipitation & $\mathrm{mm} \mathrm{day}^{-1}$ \\
\hline RAINS & precipitation corrected for losses thorough interception of crop canopy and water runoff & $\mathrm{mm}$ \\
\hline $\mathrm{RD}$ & rooting depth & $\mathrm{cm}$ \\
\hline $\mathrm{Ri}$ & incident radiation arriving at soil-residue system & $\mathrm{MJ} \mathrm{m}^{-2}$ \\
\hline ROFF & water runoff & $\mathrm{mm}_{\text {day }}{ }^{-1}$ \\
\hline Rss & radiation arriving at soil surface through the mulch of crop residues & $\mathrm{MJ} \mathrm{m}^{-2}$ \\
\hline RUE & radiation-use efficiency & $\mathrm{g} \mathrm{DM} \mathrm{MJ}^{-1}$ \\
\hline SR & mass of surface residue & $\mathrm{Mg} \mathrm{ha}^{-1}$ \\
\hline SRW & amount of water currently held by surface residue & $\mathrm{mm}$ \\
\hline SRWSAT & maximum amount of water that can be retained by crop residues & $\mathrm{mm}$ \\
\hline VITIRCARB & allocation to grain & g grain $\mathrm{g}^{-1}$ plant day ${ }^{-1}$ \\
\hline Q0 & parameter of the end of first stage soil evaporation & $\mathrm{mm}$ \\
\hline
\end{tabular}

Acknowledgements: The work was supported by funds from the Centre de Coopération Internationale en Recherche Agronomique pour le Développement (CIRAD), Centro Internacional de Mejoramiento del Maíz Y Trigo (CIMMYT) and the French Ministry of Foreign Affairs. We thank Cedric Lamalle for technical assistance in running the computer model and Daniel Mendham for revision of the English.

\section{REFERENCES}

[1] Affholder F., Modélisation de culture et diagnostic agronomique régional : mise au point d'une méthode et application au cas du maiis chez les petits producteurs du Brésil Central, Ph.D. dissertation, INA-PG, Paris, 2001.
[2] Andales A.A., Batchelor W.D., Anderson C.E., Farnham D.E., Whigham D.K., Incorporating tillage effects into a soybean model, Agric. Syst. 66 (2000) 69-98.

[3] Anderson J.R., A framework for examining the impacts of climate variability, in: Muchow R.C., Bellamy J.A. (Eds.), Climatic risk in crop production: models and management for the semiarid tropics and subtropics, CAB International, Wallingford, UK, 1991, pp. 317.

[4] Assad E.D., Chuva nos Cerrados:análise e espacialização. EMBRAPA-CPAC/SPI, Brasilia, DF, 1994.

[5] Brisson N., Mary B., Ripoche D., Jeuffroy M.H., Ruget F., Nicoullaud B., Gate P., Devienne-Baret F., Antonioletti R., Durr C., Richard G., Beaudoin G., Recous S., Tayot X., Plenet D., 
Cellier P., Machet J.M., Meynard J.M., Delécolle R., STICS: a generic model for the simulation of crops and their water and nitrogen balances. I. Theory and parameterisation applied to wheat and corn, Agronomie 18 (1998) 311-346.

[6] Brisson N., Gary C., Justes E., Roche R., Mary B., Ripoche D., Zimmer D., Sierra J., Bertuzzi P., Burger P., Bussière F., Cabidoche Y.M., Cellier P., Debaeke P., Gaudillère J.P., Hénault C., Maraux F., Seguin B., Sinoquet H., An overview of the crop model STICS, Eur. J. Agron. 18 (2003) 309-332.

[7] Bussière F., Cellier P., Modification of the soil temperature and water content regimes by a crop residue mulch: experiment and modelling, Agric. For. Meteorol. 68 (1994) 1-28.

[8] Caamal-Maldonado J.A., Jimenez-Osornio J.J., Torres-Barragan A., Anaya A.L., The use of allelopathic legume cover and mulch species for weed control in cropping systems, Agron. J. 93 (2001) 27-36.

[9] Evers G., Agostini A., No-tillage farming for sustainable land management: lessons from the 2000 Brazil Study Tour. TCI Occasional Paper Series No. 12, Soil Fertility Initiative, 2001.

[10] Findeling A., Ruy S., Scopel E., Modeling the effects of a partial residue mulch on runoff using a physically based approach, J. Hydrol. 275 (2003) 49-66.

[11] Gilley J.E., Finkner S.C., Varvel G.E., Runoff and erosion as affected by sorghum and soybean residue, Trans. ASAE 29 (1986) $1605-1610$.

[12] Gregory J.M., Soil cover prediction with various amounts and types of crop residues, Trans. ASAE 25 (1982) 1333-1337.

[13] Kladivko E.J., Tillage systems and soil ecology, Soil Till. Res. 61 (2001) 61-76.

[14] Lal R., Mulching effects on runoff, soil erosion and crop response on alfisols in western Nigeria, J. Sustain. Agric. 11 (1998) 135154.

[15] Lilienfein J., Wilcke W., Do Carmo Lima S., Vilela L., Thomas R., Zech W., Nutrient concentrations in soil solution of some Brazilian Oxisols under conventional and no-tillage systems in the early part of the rainy season, Aust. J. Soil Res. 38 (2000) 851-866.

[16] Macena F., Corbeels M., Scopel E., Affholder F., Pinto H.S., Characterising effects of surface residues on evaporation for a simple water balance model, Proceedings 2nd World Congress on Conservation Agriculture, Foz do Iguaçu, Brazil, August 10-15, 2003 , Vol. II, pp. 522-524.
[17] Muchow R.C., Hammer G.L., Vanderlip R.L., Assessing climatic risk to sorghum production in water-limited subtropical environments. II. Effects of planting date, soil water at planting, and cultivar phenology, Field Crops Res. 36 (1994) 235-246.

[18] Rao K., Steenhuis T., Cogle A., Srinivasan S., Yule D., Smith G. Rainfall infiltration and runoff from an alfisol in semi-arid tropical India. I. No-till systems, Soil Till. Res. 48 (1998) 51-59.

[19] Ritchie J.T., Model for predicting evaporation from a row crop with incomplete cover, Water Resour. Res. 8 (1972) 1204-1213.

[20] Ross P.J., Williams J., McCown R.L., Soil temperature and the energy balance of vegetative mulch in the semi-arid tropics: II Dynamic analysis of the total energy balance, Aust. J. Soil Res. 23 (1985) 515-532.

[21] Savabi M.R., Stott D.E., Plant residue impact on rainfall interception, Trans. ASAE 37 (1994) 1093-1098.

[22] Scopel E., Findeling A., Conservation tillage impact on rainfed maize production in semi-arid zones of western Mexico. Importance of runoff reduction, in: Garcia-Torres L., Benites J., MartinezVilela A. (Eds.), Conservation Agriculture, a worldwide challenge, 2001, Vol. II. pp. 179-184.

[23] Scopel E., Muller B., Arreola Tostado J.M., Chavez Guerra E., Maraux F., Quantifying and modelling the effects of a light crop residue mulch on the water balance: an application to rainfed maize in western Mexico, XVI World Congress of Soil Science, Montpellier, France, August 20-26, 1998.

[24] Séguy L., Bouzinac S., Trentini A., Côrtes N.A., L'agriculture brésilienne des fronts pionniers, Agric. Dév. 12 (1996) 1-61.

[25] Stewart B.A., Lal R., El-Swaify S.A., Sustaining the resource base of an expanding world agriculture, in: Lal R., Pierce F.J. (Eds.), Soil management for sustainability. Soil and Water Conservation Society, US, 1991, pp. 125-144.

[26] Swift M.J., Heal O.W., Anderson J.M., Decomposition in terrestrial ecosystems, University of California Press, Berkeley, CA 1979.

[27] Todd R.W., Klocke N.L., Hergert G.W., Parkhurst A.M., Evaporation from soil influenced by crop shading, crop residue and wetting regime, Trans. ASAE 34 (1991) 461-466.

[28] Unger P.W., Wheat residue management effects on soil water storage and corn production, Soil Sci. Soc. Am. J. 50 (1986) 764-770.

[29] Wagner-Riddle C., Gillespie T.J., Hunt L.A., Swanton C.J., Modeling a rye cover crop and subsequent soybean yield, Agron. J. 89 (1997) 208-218. 